\title{
Kam Louie (ed.), Hong Kong Culture: Word and Image
}

Hong Kong, Hong Kong University Press, 2010, 312 pp.

\section{Fiona Yuk-wa Law}

\section{(2) OpenEdition}

\section{Journals}

Electronic version

URL: http://journals.openedition.org/chinaperspectives/5979

DOI: 10.4000/chinaperspectives.5979

ISSN: 1996-4617

\section{Publisher}

Centre d'étude français sur la Chine contemporaine

\section{Printed version}

Date of publication: 1 October 2012

Number of pages: $90-91$

ISSN: 2070-3449

\section{Electronic reference}

Fiona Yuk-wa Law, « Kam Louie (ed.), Hong Kong Culture: Word and Image», China Perspectives [Online] 2012/3 | 2012, Online since 01 October 2012, connection on 24 September 2020. URL : http://

journals.openedition.org/chinaperspectives/5979; DOI : https://doi.org/10.4000/chinaperspectives. 5979

This text was automatically generated on 24 September 2020.

(c) All rights reserved 


\title{
Kam Louie (ed.), Hong Kong Culture: Word and Image
}

Hong Kong, Hong Kong University Press, 2010, 312 pp.

\author{
Fiona Yuk-wa Law
}

1 It is always an inexhaustible task to define and explain what Hong Kong culture is, and the result would usually be a staggering one. This timely anthology sheds light on grounding the uniqueness of Hong Kong's cultural scene in a specific context of the post-1997 era via an intellectual trajectory of word and image. Edited by Kam Louie, Dean of the Faculty of Arts at the University of Hong Kong and a prolific scholar in Chinese literature, the 13 essays in this book come from a conference convened by the Faculty of Arts on the topic of "Post-1997 Hong Kong culture: Word and image" in 2007. Hong Kong-based and overseas scholars from diverse disciplinary backgrounds contribute their readings of Hong Kong

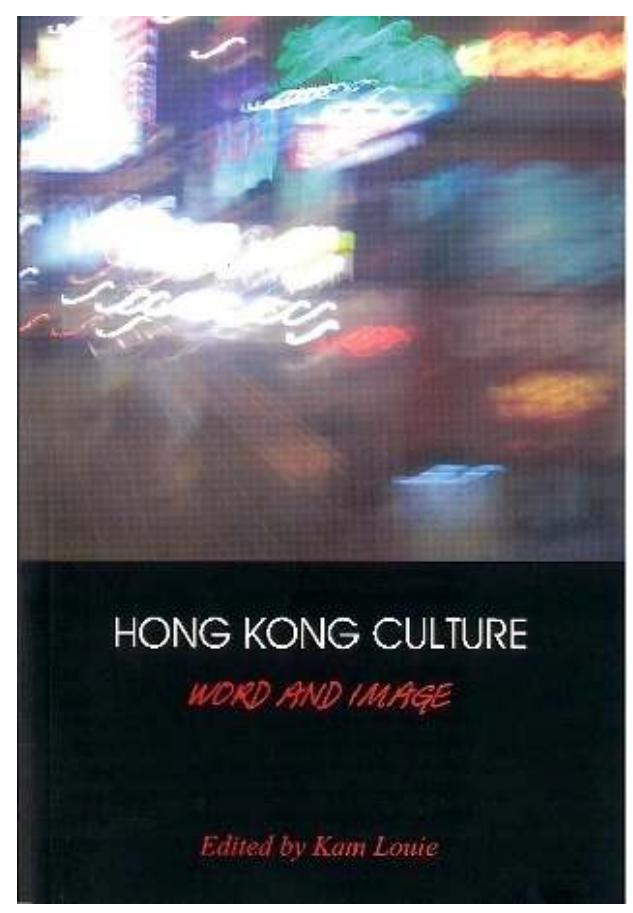
culture from a wide range of academic interests. Having 1997 as a point of departure and contact, these essays review the long-ranged chinese roots and global influences that are intricately related to the territory's recent transmutations through attending to its sociopolitical background in the analyses of film, literature, performance art, and the cityscape, etc.

2 In light of the attempt to "explore the development of Hong Kong's cultural scene under the 'one country, two systems' framework" and "to critically explore Hong Kong 
as a polyphonic, diverse source of cultural 'texts"' (p. 1) under the given topic, Louie in his introduction suggests several phrases to inspire readers' understanding of Hong Kong in uncompromising terms, such as Hong Kong being a "cultural fault-line" in a shaky geographical terrain, a "translation space" between Chinese-ness and Westernness, a "cultural hub" that joins vernacular culture with cosmopolitanism, a "multifaceted, polyphonic culture that resists easy homogenization" (p.2), a "transmission zone" where artists and audiences are energised (p. 5), and so on. These phrases and descriptions are indicative in rendering and reinforcing Hong Kong as a site of dynamic cultural studies on an unstable borderline of ruptures and connection. The editor and the authors refuse to rest on an easy, generalised discussion by simply defining Hong Kong culture within the nexus of East-West hybridity; rather, they marble their discussions on various views of Hong Kong's cultural scene with a solid contextual knowledge of the city without manipulating excessive theoretical terminologies.

3 Unlike many anthologies, this book is not divided into sections to make a clear-cut division between discussions on word and image, so that the 13 essays are not rigidly defined by their scopes of interest. However, a subtle route from word to image is found in the order of chapters, which may suggest an understandable path from the local (vernacular Cantonese culture and its related language issues that involve the Chinese and English language) to the global (circulation of images in the context of globalisation). This book review does not strictly follow this implied local-global nexus, while readers may note that my order of writing about these chapters in fact suggests an underlying cobweb of cultural influence between Hong Kong, China, Asia, and the West, and that such a sphere of influence is what Louie and the authors would like to emphasise in their discussions of Hong Kong's unique cultural nourishment under the diverse but somehow crisscrossing influence of postcolonialism, orientalism, postsocialism, postmodernism, and the emergence of localism and cultural preservation.

4 This delightful journey of word and image starts with John M. Carroll's chapter, which provides a comprehensive overview of Hong Kong's unique decolonisation process by outlining crucial changes and continuities in the city's political realities between 1997 and 2007. Carroll's historical framework succinctly points out the difficulties and complexities involved in defining Hong Kong's postcolonial history, especially when the SAR's first decade was rocked by global calamities such as SARS and the Asian Financial Crisis. The aftermaths of the local and global crises, namely the city's political disappointment and the emergence of political commemoration-type demonstrations and marches by Hong Kong residents, are then further explained in Carolyn Cartier's following chapter, which investigates the realm of the performative in Hong Kong's political life through protest art. Another macroscopic account of Hong Kong's post-1997 anxiety is manifested in David Clarke's engaging essay on the "haunted city." Instead of explaining the psychic persistence of a haunting experience via a supernatural, poignant discourse of fear, the author provides a number of local examples in architecture, filmic texts, urban planning, and artworks in order to unfold the way Hong Kong's self-perceived urban landscape is narcissistically articulated in spatial terms with the existence of an implied other. While Clarke's chapter on Hong Kong's urban other focuses on the traces that can be found in the city's visual cultures, Esther M. K. Cheung's later chapter takes a close look at Hong Kong films with a different notion of the "ghostly city." Through a microscopic "spectral analysis," or 
"hermeneutic reading of the cinematic depiction of space" in three Hong Kong films made at "various moments of disjointed time in Hong Kong history," Cheung's essay "explore(s) the possibility of writing a meta-history of Hong Kong over the past thirty years" so as to see "how an allegorical reading of the ordinary, quotidian aspects of urban life offers us chances to understand the effects of eventful changes" (p. 170), namely the kairotic moment of the 1997 handover. In addition to Clarke and Cheung's chapters, Pheng Cheah also shows a special interest in Fruit Chan's films in his discussion. By critically examining Hong Kong's post-1997 situation with the city's selfcelebration of "being" a global city, Cheah situates his textual analysis of Chan's Hollywood, Hong Kong in his acute exploration of what it means to be a global city under the official imperatives of consolatory discourse and image production. In addition to analysing the "plasticity" of the global city's cultural form beneath the "hegemonic imaginary" of global dreams and the "power of the virtual image" (p. 197), this chapter, echoing Clarke and Cheung's, introduces the idea that dreams of global capitalism would be lived as nightmares by the marginalised through the lens of selfreferentiality.

Gina Marchetti's chapter focuses on another cultural fault line, or "cinematic earthquake"(p.167) resulting from globalisation. In her study of the phenomena of cinematic remake, adaptation, and global filmic traffic in the case of Infernal Affairs and The Departed, Marchetti conducts an interesting analysis of this oft-studied aspect in film studies by considering the participatory culture expressed by fan communities in blogs and online discussion groups. This combination of textual analysis and reading of diverse comments by global and local fans of the two films provides important material for expanding academic interest in the study of Hong Kong cinema in the context of global circulation of ideas and images by drawing attention to the power of public opinion. Giorgio Biancorosso's chapter, on the other hand, provides a musical scenario (which is least discussed in the study of Hong Kong cinema) about the East-West, localglobal intertextual influences via Wong Kar-wai's films and their soundtracks. Since Wong's films do not easily express attributions from other cultural texts such as literature and film, Biancorosso outlines Wong's sonic space and personal musical taste by combining an analysis of the visual elements with a detailed discussion of the use of pop compilations. The chapter focuses on the way new meanings are generated for the pre-existing music rearranged in Wong's films, so as to suggest an orbit that joins the local with the global, as well as the personal with the collective.

6 The mutual influence between Hong Kong and Hollywood or the West is like the paradox of egg or chicken, while in C. J. W.-L. Wee's chapter, the sphere of cultural influence spreads among the East Asian regions. By focusing on the intra-Asian connection and competition that lie behind post-1990s Hong Kong cinema with a discussion on the emergence of the "New" East Asia through a historical lens, Wee suggests that the shared understanding of capitalist modernisation and rapid urbanisation among these Asian regions is the mechanism that produces the "shared vision of everyday urban life" (p. 114) or "the ongoing development of urban-modern lifestyles" (p.115) in the "fractured New Asia." Such notions of the modern and the urban provide useful insights into the shaping of cosmopolitan images on Asian screens and therefore explain Hong Kong's significant position in this dynamic cultural productivity within the elusive concept of Asia. 
7 Considering the increasing number of Hong Kong-China co-productions as an example of the implementation of "one country, two systems" after the signing of CEPA (Mainland-Hong Kong Closer Economic Partnership Arrangement) in 2003, Chu Yiuwai's chapter addresses the important question of whether Deng Xiaoping's idea would necessarily guarantee "one country, two cultures" by tracing a brief history of mainland influence on Hong Kong cinema. The oft-proclaimed decline of post-1997 Hong Kong cinema and the rise of co-production in recent years are both studied in this chapter as indicative of the emerging umbrella concept of "Chinese cinema" under which, according to Chu, Hong Kong cinema's multiplicity can hardly survive (p. 144). Such a sense of crisis not only echoes earlier chapters sounding the alert over cultural mutation after 1997 but also brings to light a changing understanding of Chineseness and Hong Kong's cultural identity, which is further explored in the arena of word. Elaine Ho's chapter on biliteracy and translation reads "Hong Kong's complex linguistic geography" (p.56) through close-reading three Hong Kong poems and their English translations. By reflecting on the post-1997 official policy of biliteracy and trilingualism, and acknowledging the "dynamic interflows" between translation and postcolonial studies, Ho's analysis of the three poems suggests that the "worlding" of Hong Kong through English could point to the city's "original Chineseness" as well as its hybridity (p. 65). Douglas Kerr's chapter focuses on the place of English poetry in Hong Kong by reading Louise Ho's poems. Also attending to the poetic form, this chapter examines the way English as a "world" or "a-local" language articulates locality, migratory experiences, and cultural memory in Ho's works. Kerr's highlight of the strategic use of English in Hong Kong poetry echoes Michael Ingham's essay on Xu Xi's literary works. However, instead of a close study of the literary genre alone, Ingham makes an interesting connection between the literary and film forms by addressing to the notion of "essay" in order to unfold the critical discourse in Hong Kong's cultural production and concern for controversial issues with a critical distance. His comparative analysis of Xu Xi's essay writings and Herman Yau's "film essay" provides a profoundly notable approach in comparative study across word and image. No doubt, a "film essay" is similar to the documentary genre, and Chris Berry has extended the discussion of this non-fictional genre in his chapter on Tammy Cheung's films. Berry's detailed study of Cheung's career as an independent documentary filmmaker is instructive in mapping the alternative film scene in Hong Kong, Beijing, and Taiwan. According to Berry, this independent mode of cultural production, or "independent culture" that generates public debates through aesthetic practices, is an important part of Hong Kong's modern culture. As other authors in this volume have hinted, it is clear that freedom of speech and autonomous thought are what make Hong Kong an important cultural hub despite its potentially cracking edges.

It is easy to understand why the majority of texts analysed are films and literary works, taking into account that they are indeed representative genres of "word and image," but it may enrich the scope of scholarship if a more extensive range of cultural texts could be included. The chapters on music, other forms of visual arts, and a mixed study across cultural forms are therefore major leaps from existing scholarships. In general, although the book may not break radically new ground in building a conceptual or theoretical framework to understand Hong Kong culture, and some chapters share similar viewpoints about Hong Kong's current problems and opportunities in different dictions, the essays are all highly readable and they are all fundamental readings for courses about Hong Kong (or even postsocialist China) cultural studies with an 
emphasis on textual analysis. The book will definitely invite further scholarship in Hong Kong's literary, cinematic, and cultural studies under an ever-renewing context.

\section{AUTHOR}

\section{FIONA YUK-WA LAW}

Fiona Yuk-wa Law is a Teaching Consultant in the Department of Comparative Literature, School of Humanities, at the University of Hong Kong (l.fiona@gmail.com). 